\title{
Effectiveness of Archive Management on Record System in National Zakat Agency in Indonesia
}

\author{
Durinda Puspasari \\ Education of Office Administration \\ Universitas Negeri Surabaya \\ Surabaya, Indonesia \\ durindapuspasari@unesa.ac.id
}

\author{
Durinta Puspasari \\ Education of Office Administration \\ Universitas Negeri Surabaya \\ Surabaya, Indonesia \\ durintapuspasari@unesa.ac.id
}

\author{
Choirul Nikmah \\ Education of Office Administration \\ Universitas Negeri Surabaya \\ Surabaya, Indonesia \\ choirulnikmah@unesa.ac.id
}

\begin{abstract}
Lembaga Manajemen Infaq is one of the National Zakat Agency in Indonesia which aims to welfare underprivileged through fundraising of Zakat, Infaq, Sadaqah, and Waqaf. Activities of Lembaga Manajemen Infaq deals with the interests of the people, so that archive management is needed to support achieving Good Corporate Governance. The purpose of this research is analyzing the archive management and the effectiveness of archive management on record system in Lembaga Manajemen Infaq Surabaya. The type of this research is descriptive research, while the approach used in this research is qualitative approach. Subjects in this study are all archive employees in Lembaga Manajemen Infaq Surabaya. Using interviews as data collection techniques and data analysis techniques according to Milles and Huberman include: data reduction, data display and a conclusion drawing. Result of the research indicates: 1) archive management in Lembaga Manajemen Infaq Surabaya for activities of archives creation, archive storage, archive preservation, archive depreciation, and archive destruction carried out according to archiving procedure; 2) Lembaga Manajemen Infaq Surabaya has three activities of archive management considered as effective, these are archive creation, archive depreciation and archive destruction.
\end{abstract} agency

Keywords-effectiveness; archive management; national zakat

\section{INTRODUCTION}

Both government and private institutions require the existence of data to facilitate the flow of information. Information helps the institutions in decision making. The need for information is further processed in the archive. Archive is a main asset of institution as the memory center in accommodating all the important information. Institutions are obliged to carry out archive management according to the genuine procedure. Article 1 of Law [1] describes "Archives are records or events in various forms and media as ICT developmental results which are created and accepted by state institutions, local governments, educational institutions, enterprises, political organizations, society, and individuals in social life". Archives are created and accepted scripts or records by government, private and individual organizations concerning an event for a certain purpose in single or group stack and stored systematically to facilitate quick and easy retrieval [2].

Following procedure of archive management is required to archive preservation. It will accelerate the retrieval activity of archive and provide the easier decision making process. At the time information in the stored archive is required, it must be available to related parties. Archive management activities in institutions consists of archive creation, archive storage, archive preservation, archive depreciation, and archive destruction which must be ruled according suitable filing system. Archive management consists of six main activities: archive creation, archive selection, archive control, archive storage, archive preservation, and archive destruction [3]. A proper archive management provides a good record system.

Both profit and non profit institutions require archive management to support the activities of the organization. The more complex activity of an institution, the greater filing system is needed. One of the nonprofit institutions has perform archive management is Lembaga Manajemen Infaq (LMI) Surabaya. LMI is one of the National Zakat Agency in Indonesia aims to welfare dhuafa (underprivileged) through ZISWAF (Zakat, Infaq, Sadaqah, and Waqaf) fundraising from individual and CSR (Corporate Social Responsibility) fund. LMI programs have dialed to help dhuafa. Activities of LMI deals with the interests of the people, so that archive management is needed to support archiving GCG (Good Corporate Governance).

Based on preliminary study, National Zakat Agency LMI Surabaya handles incoming and outgoing mail using centralization principle through only one-door service by 
archive unit, it impacts the longer time in processing incoming and outgoing mail. Archive storage activity also come about less than a quick, it makes the needed archive lost often. Problem listed causes longer duration of retrieval process and miss information. Archive preservation also inhibited by lending process. It occurs when someone borrows archive and failed to return back. In addition, non-archival graduated employees also being one of problem cause factor. This problem of archive management will affect retrieval process. The more volume of stored archive will also be complex and affecting the optimization of record system.

Based on the issue from the preliminary study, a research on ""Effectiveness of Archive Management on Record System in National Zakat Agency LMI Surabaya" must be conducted.

The formulation of the problem are:

1) How does archive management in National Zakat Agency LMI Surabaya?

2) How does the effectiveness of archive management in National Zakat Agency LMI Surabaya?

\section{LITERATURE REVIEW}

\section{A. Archive}

Archive is one of the office work products. Other office work products are forms, letters, and reports [4]. Archives are created and accepted manuscripts or records by government, private and individual organizations concerning an event for a certain purpose in single or group stack and stored systematically to facilitate quick and easy retrieval [2]. According to [2] the characteristics of good archive are: "1) collection of scripts that have value for use; 2) stored systematically which not only means the archives are placed and arranged in alphabetical, date or number order, but also explain subject classification, geographical origin and the creator of the document; c) archives must be quickly provide when needed".

\section{B. Types of Archives}

Based on [1] about Basic Provisions of Archives, archive is divided as follows:

1) Dynamic archive is archives that are still needed directly in the planning, implementation or still used directly on the state administration. Dynamic archives are divided into two, i.e.:

a) Active archive is archives that are directly and continuously required and used in the administration of day-to-day operations and are still managed by the managing unit;

b) Inactive archive is archives that are indirectly and incessantly required and used in the administration of day-to-day administration and managed by the archive center.

2) Static archive is archives that are not used directly in the planning, implementation or not used directly on the state adminsitration. According to the provisions, archive works as a tool for directly or indirectly planning on state administration.

\section{Filing}

According to [5], "filing is a process of reception, collection, arrangement, preservation and storage of documents according to certain systems to provide easy dan quick retrieval". Law [1] about Filing states that "The scope of filing is the overall determination of policy, archive development, and archive management in a national archive system supported by human resources, infrastructures and facilities, and other resources in accordance with the provisions of law. Archiving functions are: 1) document storage tool; 2) library auxiliary, especially in large organizations with centralized system; 3) organizational tracker record; 4) streamline work; 5) problem solving tools of organizations; 6) information provision tools; 7) sources of information about activities occurring in the office [6]

\section{Filing Effectiveness}

Filing effectiveness is the organization's ability to ensure the safety and provision of the documents containing the correct data or information, to the right person, at the right time, and at the lowest possible cost. This understanding is in line with archival purposes in Law [1] 43/2009 on Filling, archive management aims to ensure the safety and security of archives as evidence of accountability in the life of society, nation and state. In this aspect, effective filing refers to the state of the gated archives, not lost, the confidential information still keep from unauthorized parties, and not damaged or physically durable. If effectiveness of organization is measured from the extent goal achievement, then the effectiveness of filing is measured from the extent goal achievement of the archives.

Achieving the effectiveness of filing need a concern to influence factors. According to [7] there are four things that must be considered:

1) Correct filing system in each organization or agency;

2) Storage procedure and usage rules of documents;

3) Arranging the archives evenly;

4) Upgrading worker competency.

\section{E. Archive Management}

\section{1) Archive Creation}

Archive management activity starts from creating the document/archive. The archive can be sourced to individuals or groups and the archive source of an organization comes from internal and external archives. The activity of creating the documents also called as correspondence.

Correspondence is the most important activity in the office that manages the procedures of incoming mail and outgoing mail which contains different steps. After receiving incoming mail from an external party, it must be registered. There are three alternative register tool, then the letter will be distributed to the processing unit to be processed and followed up. After the processing is completed, the mail will be stored. As for the outgoing mail, after the letter has been made and ready it must be registered. Once registered, the mail ready to distribute. 


\section{2) Archive Storage}

Archive storage must be well-managed to provide easy and quick retrieval. There are three possibilities archive storage principles according to conditions of the organization:

a) Principle of centralization, which all documents are stored in one storage center. Subordinate units need to use the documents may contact to obtain and use as required;

b) Principle of decentralization, which management and storage of documents is submitted to each unit;

c) Principle of combination, which each unit stores its own document under centralized system control.

In addition to storage principles, according to [8] there are several filing system:

a) Alphabetical filing system, the most widely used system in many companies because archives are stored in alphabetical order given to the person's name, organization or company or subject. It is suitable for small organizations or for individual archives;

b) Numerical filing system, this system suitable for confidential archives because its code only known by certain people only. Archives are stored in numerical order coded by name of person, organization or company or subject and this system can also combine with an alphabetical system to keep the order of archival storage;

c) Geographical filing system, which is suitable for organizations that divide their territory by geographical region. Archives are stored by geographic name or region code and also can be combined with alphabetic classification to keep their order;

d) Subject filing system, is a suitable system for organizations with various subjects. Archives are stored based on certain topics or subjects on the organization's or company's activities;

e) Chronological filing system, is temporary system before the archive is classified based on a particular classification system. Archives are stored in chronological order of date-month-year.

\section{3) Archive Preservation}

According to [9] "archive preservation is an effort to keep the archive is not damaged as long as still has value for use in physical condition. Thus, in order to preserve the archive properly, several factors causing archive jn damage and how to prevent it must be considered". Purpose of preserving and securing the archive according to [5] are: "a) prevent damage to the archive effectively and efficiently; b) facilitate coordination in the execution of tasks; c) minimize disruption to the organization; d) prevent the occurrence of disasters; e) prevent harm to employees and the public; f) protect the property of the organization or company ".

4) Archive Depreciation
According to [9] "archive depreciation is the activity of reducing the number of records by transferring inactive archives from processing units to archival units, destruct expires archives, and archive submission to archive institutions".

\section{5) Archive Destruction}

Destruction of archives execute when the archive is no longer useful for office operations and for some reason unused archives are kept as archaic archives and have no historical value. States destruction of archives or documents when stored documents in the organization are no longer needed or expired [9]. According to [3] the destruction of archives can be done in various ways as follows: "a) shattering the document through paper shredder machine; b) burning thoroughly to ashes; c) buried in soil (less effective); d) manually tearing into small pieces; e) using a paperdestruction machine ".

\section{A. Types of Research}

\section{METHODOLOGY}

This research is descriptive research, while the approach used in this research is qualitative approach. This study aims to describe a problem or phenomenon that occur in the field

\section{B. Subjects and Research Objects}

Subjects in this study are three employees in the archives field at each division in National Zakat Agency LMI Surabaya. In this research, the object of research is archive management and effectiveness of filing system in National Zakat Agency LMI Surabaya which is located at Jalan Barata Jaya Street XXII / 20 Surabaya.

\section{Data Collection Technique}

Data collection techniques in this study using interviews to the archive employees in National Zakat Agency LMI Surabaya.

\section{Data Analysis Technique}

This study uses analytical techniques according to Miles and Huberman, which consists of data reduction, data display, and conclusion drawing.

\section{RESULTS}

Based on the results of interviews conducted by the researcher to Mr. Luqman Hadi, Mr. Indiar Febrianosa, and Mrs. Kartika Dewi related to archive management described as follows:

\section{A. Archive Creation}

1) Basic Law of archive creation is all processes related to the archives are regulated in East Java Governor Regulation No. 26/2009 on Filing in East Java Provincial Government and Government Regulation of the Republic of Indonesia Number 28 of 2012 on Implementation of Law Number 43 of 2009 about Filing. The regulation also being a premise 
implementing ISO 9001/2008 in National Zakat Agency LMI.

2) Procedures of handling incoming mails consist of: receipt of letters centered on the front office either by post, e-mail, or fax to sort and keep the security and check the truth of the address, then registry incoming letter into the agenda book and distribute to Head Office for the granting of a disposition to obtain follow-up, distribute the letters to the intended party, and after the letter has been processed, the mail is stored as an archive at the institution using cabinet storage, filing cabinet, rack, ordner, and snellhecter. Storage is done aiming that the letter can be found quickly and precisely when needed. While the outgoing mail handling procedure consists of: preparing the concept of letter made by each division. Then, the drafted letter submitted to the Head of Office for review in order to get approval and initials. Duplicate the letter and then register into the outgoing agenda book to obtain the letter number from general operational section to get cover letter with the full address and ready to be sent based on the address, the other copy of letter is stored as the institution's archive.

3) Archive creation in terms of handling incoming and outgoing mailings is already effective. It is because the incoming mail or outgoing mail using manually system through disposition sheet and agenda book which ease administrative staff in performing procedures for processing incoming and outgoing mail.

\section{B. Archive Storage}

1) Storage system in dynamic archives of the financial division and the collection division consisting of routine collection, new collection, and incidental collection is chronological filing systems, while for the empowerment division using the subject filing system. The different filing system because the different needs of each division. Storage in cabinets using ordner. Archives are classified as dynamically active in this institution is one year running, whereas if the archive has reached two years or more (inactive dynamic archives) it will be depreciated. Inactive dynamic archives are stored based on chronological filing system, where letters are grouped in the same month and year, then stored in folders and put into archive storage.

2) The archive stored with principle of decentralization which each division is responsible for storing and managing the files themselves. While inactive dynamic archives using the principle of centralization, the archives are stored and centralized in the archive depository.

3) Lack of administrative staff who handle the archive so that the necessary archival training for administrative personnel who handle the archive.

4) Archive storage system has not been effective because only two divisions are using the same chronological system (financial division and collection division). While empowerment division using subject filing system by using the principle of decentralization. The archive storage is under the responsibility of each division and the other division can not directly access the archive if necessary.

\section{Archive Preservation}

1) Preservation of active dynamic archives and inactive dynamic archives to ensure information continuity on the archive is made available with sufficient means to maintain the physical form of the archive, such as cabinets, filing cabinets, racks, ordner and snellhecter. In addition, cleaning the room and archive depository, use camfer or camphor, use air conditioner, and provide fire extinguishers.

2) The preservation of the archive has not been effective due to the unavailability of the use of archive damage materials (such as fumigation), so it has not been able to minimize and protect the dangers that could threaten the destruction of the archives, one of which attacks the paper eater.

\section{Archive Depretiation}

1) Depreciation of the archive depend on the type of archive. If the age of the archive has reached 4 years, it must be depreciated.

2) The process of archive depreciation has been effective, because the management of the archive with a small amount will be easier than with large quantities. Storage volume of the archive that has been depleted its storage can be reduced.

\section{E. Archive Destruction}

1) The process of destruction of the archive is a continuation of the process of archive depreciation where the age of archives has reached 5 years newly destroyed. Destruction of the archive using paper shredder is considered as the safe way for the expired record or have no usage value for LMI Surabaya.

2) Archive destruction has been effective. The destruction of archives is an effort to reduce the volume of archives that grows daily and save archive storage space.

\section{DISCUSSION}

A. Archive Management in National Zakat Agency LMI Surabaya

\section{1) Archive Creation}

Archive creation in the National Zakat Agency LMI starts from preparing the concept of a letter created by each division. Then the concept of the letter is submitted to the Head Office for review, approval and initials. Then, register the mail into agenda book of outgoing mail. Registering in the outgoing book of agenda to get the reference letter number by the general operational section. After the letter covered and have been filled with the complete address the letter is ready 
to be sent based on the intended address. The letter is needed to be copied and the copied letter can be stored as an archive of the institution. Letter creation should be supported by registering into the agenda book then the institution has authentic evidence of archive creation if the letter does not reach the address.

2) Archive Storage

Archive storage system in National Zakat Agency LMI Surabaya is different in each division because of different needs. Three divisions in the LMI National Zakat Agency using different archive storage systems is financial division and division of collection (routine collection, new collection, and incidental collection) using chronological filing system, while the empowerment division uses subject filing system. National Zakat Agency LMI has implemented several archive storage systems according to applicable theory. As known there are three filing system i.e. alphabetical filing system, chronological filing system, numerical filing system, geographical filing system, and subject filing system. In accordance to research journal of [10] entitled "Dynamic Archive Storage and Retrieval Procedure at West Sumatera Provincial Council Secretariat Office" which one of the results shows active archive storage system applied is subject filing system. The result are supported [11] that concluded archives and records management increased facility to acess information, transparency and accountability.

3) Archive Preservation

LMI National Zakat Agency preserve active dynamic archives as inactive dynamic archives by providing adequate archive storage. It is to maintain whole physical of archive. Archive preservation using cabinet, filing cabinet, rack, odner, and snellhecter. In addition, cleaning the room and archive storage, use of camfer or camphor, setting the room using air conditioning, and provide fire extinguishers are need to do. National Zakat Agency LMI has been trying to keep the archive to avoid the archival damage that could happen any time, whether it is caused by small animals destroyers or depleted by time. Research journal of [12], entitled "Dynamic Archive Management System in Library, Archives and Documentation Office of South Coast Regency" which one of the results shows storage equipment are divider, folders, guide and racks.

\section{4) Archive Depreciation}

Depreciation of archives at National Zakat Agency LMI aims to minimize large number of archive. If there is no depreciation, the archive will be multiplied and fulled the depository. Archives National Zakat Agency LMI will depreciate after reached 4 years. It means the over 4 years archives considered to have no usage value. Archive depreciation is the activity of reducing the number of records by transferring inactive archives from processing units to archival units, destruct expires archives, and archive submission to archive institutions [9].

5) Archive Distruction

Archive destruction activity in National Zakat Agency LMI executed after archive depreciation. Depreciated archives reached 5 years will be immediately destroyed. Archive destruction in National Zakat Agency LMI is using a paper shredder. Paper shredder allows the destroyed archives are deemed to be unreadable for abusement. Archive destruction aims to reduce the unused static archives. In line to the opinion, [3] also explain that "the destruction of archives can be done in various ways as follows: "1) shattering the document through paper shredder machine; 2) burning thoroughly to ashes; 3) buried in soil (less effective); 4) manually tearing into small pieces; 5) using a paper-destruction machine".

\section{B. Effectiveness of Archive Management on Record System in National Zakat Agency LMI Surabaya}

The management of archive in National Zakat Agency LMI viewed in several activities, i.e. archive creation, archive storage, archive preservation, archive depreciation, and archive destruction classified as effective but also classified as less effective for some certain activities as follows:

1) Archives creation in National Zakat Agency LMI is considered as effective because incoming and outgoing mail has been handled using disposition sheets and books to facilitate administrative staff. The procedure of archieve created should be verify by organization leader [13]. In addition, recording of archieve must be managed by competent employee [14].

2) Archive storage in National Zakat Agency LMI is considered as not effective because the divisions use different archive storage system and impacted each division could not directly accessing the archive. The condition are similiar with [15] which the record clasifications focused on manual record management.

3) Archive preservation in National Zakat Agency LMI is considered as not effective because has not using archive damage prevention materials (such as fumigation) yet.

4) Archive depreciation in National Zakat Agency LMI is considered as effective because in every 4 years expired archive will be depreciated. It automatically will reduced the expired archives.

5) Archive destruction in National Zakat Agency LMI is considered as effective because the distruction will be apllied for over 5 years archives to saving space of archive depository.

Entirely archive management in National Zakat Agency LMI classified as effective for creation, depreciation, and destruction of archives and for archive storage and preservation still considered as not effective. Whereas according to [7] there are four things must be considered achieving the effectiveness of record system:

1) Correct filing system in each organization or agency;

2) Storage procedure and usage rules of documents; 
3) Arranging the archives evenly;

4) Upgrading worker competency.

Thus the weaknesses archive storage and preservation need to be re-evaluated by National Zakat Agency LMI for better process of archive management.

\section{ACKNOWLEDGMENT}

Archive Management in National Zakat Agency LMI Surabaya consists of several activites i.e. archive creation, archive storage, archive preservation, archive depreciation, and archive destruction are well-executed according to archive management procedure.

Only three activities of archive management have been effective in National Zakat Agency LMI Surabaya, that are archive creation, archive depreciation and archive destruction. While archive storage and archive activity have not been effective yet.

\section{REFERENCES}

[1] Undang-undang Republik Indonesia Nomor 43 Tahun 2009 tentang Kearsipan.

[2] Y. Suraja, “Manajemen Kearsipan”. Malang: Dioma, 2006.

[3] I. C. Dewi. "Manajemen Kearsipan”. Jakarta: Prestasi Pustaka, 2011.

[4] Z. Amsyah, "Manajemen Kearsipan". Jakarta: Gramedia Pustaka Utama, 2014.

[5] S. Endang, et al., "Modul Mengelola dan Menjaga Sistem Kearsipan". Jakarta: Erlangga, 2009.

[6] D. J. Priansa and A. Garnida, "Manajemen Perkantoran Efektif, Efisien, dan Profesional". Bandung: Alfabeta, 2015.

[7] T.L. Gie, “Administrasi Perkantoran Modern”. Yogyakarta: Liberty, 2009.

[8] I. Nuraida, "Manajemen Administrasi Perkantoran". Yogyakarta: PT. Kanisius, 2014.

[9] A. Sugiarto and T. Wahyono, "Manajemen Kearsipan Elektronik". Yoyakarta: Gava Media, 2014.

[10] Rusdawati and Ardoni, Sistem Penyimpanan dan Prosedur Temu Kembali Arsip Dinamis Aktif di Kantor Sekretariat DPRD Provinsi Sumatera Barat. "Jurnal Ilmu Informasi dan Perpustakaan (Online)", Vol. 2, No. 2, 2014. pp. 22-32.

[11] A. C. de Mingo and A. C. i Martíne, Improving Records Management to Promote Transparency and Prevent Corruption. "International Journal of Information Management", Vol. 38, 2018. pp. 256-261.

[12] H. Fajri and Syahyuman, Sistem Pengelolaan Arsip Dinamis Aktif di Kantor Perpustakaan Arsip dan Dokumentasi Kabupaten Pesisir Selatan. "Jurnal Ilmu Informasi dan Perpustakaan (Online)", Vol. 1, No. 1, 2012. pp. 409-417.

[13] D. Basu, et al., The Importance of Paper Records and Their Preservation Period in Acentral Sterile Supply Department: an Experience From a Oncologycenter in Eastern India. "Journal of Infection and Public Health", Vol. 10, 2017. pp. 685-687.

[14] E. C. Goodman, Records Management as an Information Management Discipline-a Case Study From Smith Kline Beecham Pharmaceuticals. "International Journal of Information Management", Vol. 14, 1994. pp. 134-143.

[15] U A. Mokhtar and Z. M. Yusof, Records Management Practice: The Issues and Models for Classification. "International Journal of Information Management”, Vol. 36, 2016. pp. 1265-1273. 